\title{
Kernos
}

Revue internationale et pluridisciplinaire de religion grecque antique

$23 \mid 2010$

Varia

\section{Game boards or offering tables?}

Some remarks on the Minoan 'pierres à cupules'

\section{Nicola Cucuzza}

\section{Q OpenEdition \\ 1 Journals}

\section{Electronic version}

URL: http://journals.openedition.org/kernos/1574

DOI: 10.4000/kernos. 1574

ISSN: 2034-7871

\section{Publisher}

Centre international d'étude de la religion grecque antique

\section{Printed version}

Date of publication: 1 January 2010

Number of pages: 133-144

ISSN: 0776-3824

\section{Electronic reference}




\title{
Game boards or offering tables? Some remarks on the Minoan 'pierres à cupules'
}

\begin{abstract}
From an archaeological point of view, the recognition between religious and gaming activities is very uneasy. This is true also for the so-called Minoan pierres à cupules (or Minoan kernoi or "stone slabs with depressions") whose most impressive specimen is surely the well known table à offrandes found in the Minoan palace at Mallia. After the most recent works on the subject (by H. Whittaker and N. Hillbom), the interpretation of the pierres $\grave{a}$ cupules as game board is now prevailing; however, their possible religious function can not be disregarded. The paper aims to check the methodological problems involved in the study of these pierres, starting from the available archaeological evidence.
\end{abstract}

Résumé : Les découvertes liées au déroulement des pratiques de culte sont souvent difficiles à distinguer, sur le plan archéologique, de celles qui ont à voir avec la simple dimension du jeu. Cette difficulté d'interprétation se pose de façon particulièrement évidente pour les tables à cupules (ou kernoi minoens ou stone slabs with depressions), dont la célèbre table à offrande du palais minoen de Mallia offre un exemplaire monumental. Même si l'interprétation des tables de jeu (à laquelle se réfèrent les plus récentes contributions de H. Whittaker et N. Hillbom) est probablement prédominante, celle liée à la religion ne peut pas être facilement exclue pour ces dispositifs. Cette analyse se propose par conséquent d'attirer l'attention sur les problèmes méthodologiques suscités par l'étude des tables à cupules, à partir des témoignages archéologiques disponibles.

Given the absence of explicit literary or iconographic sources, it is often difficult to establish whether certain objects brought to light by archaeological excavations have a religious or gaming function. This problem has been addressed, from a methodological point of view, by C. Renfrew in his book The Archaeology of Cult: "The recognition of cult must be on the basis of context". ${ }^{1}$ Games as well as religious practices follow well-established rituals. The required expressive actions (such as digging a hole to bury certain objects) are either the same or very similar. From an archaeological point of view, the distinction between religion and game is always difficult to determine; according to Renfrew, "ritual has a more serious purpose, and is often conducted in an atmosphere of solemnity". ${ }^{2}$ Atmosphere is, however, very difficult to ascertain in archaeological terms. Moreover, a high technological level and the invest-

\footnotetext{
${ }^{1}$ RENFREW (1985), p. 15.

2 ReNFrew (1985), p. 15.
} 
ment of large economic resources are not exclusive to the sphere of religion as opposed to that of games (even if sports are excluded from the definition of "game").

Archaeological context cannot always solve our interpretative doubts: the borderline between gaming and religious rituals is, if anything, even more blurred when we examine the data concerning the ages in life when games are the main activity: are the miniature vessels in children's tombs burial offerings or simple games? What exactly was a game in antiquity? The different purposes of play - recreational, educational and social - render the issue even more complex.

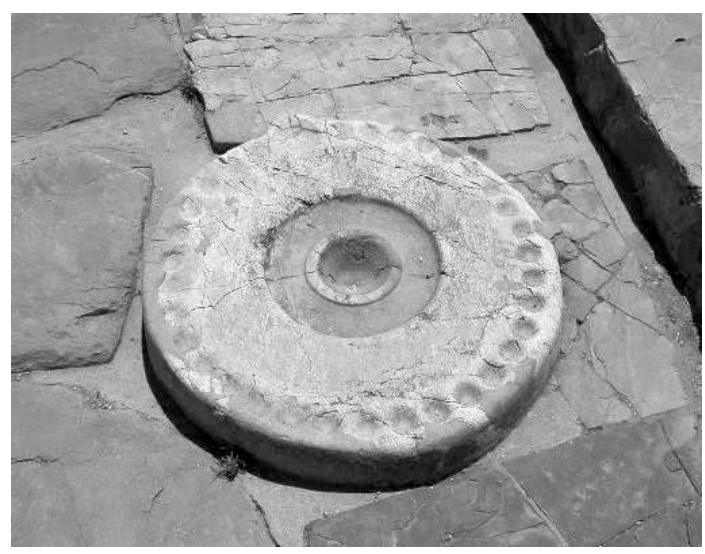

Fig. 1

In this article I will examine the so-called pierres à cupules ${ }^{3}$ from the Minoan and Mycenaean cultures. ${ }^{4}$ By far the most famous pierre is without doubt the one discovered in the Minoan palace at Mallia (Fig. 1).5 Carved in a single cylindrical stone block, it has 34 circular holes arranged along its circumference, one larger than the others, while there is an almost hemispherical large hole at the centre. The stone is sunk into the paved floor of a room at the south-western corner of the central court which opens onto this space; the room is located at the southern entrance to the palace and just south of a very large staircase. A bench on the western side was possibly used together with the stone (probably to facilitate the activities carried out on its upper surface). In 1928, in a seminal work, F. Chapouthier identified the stone as a kernos, based on Athenaeus's description of this type of vessel: according to the French scholar, the holes were used for the offering of first fruits. ${ }^{6}$ If correct, the Mallia stone would thus be an offering table for a ritual very similar to the Eleusinian panspermia.

The Mallia table is the most monumental of several examples that have been documented both at Mallia and in other Minoan settlements and cemeteries (Fig. 2). They consist of circular holes cut into the surface of stone slabs, most

\footnotetext{
${ }^{3}$ Hillbom (2003); WhitTaker (2002).

${ }^{4}$ Cf. Hillbom (2005), p. 274-277, 330-335, 347-359.

${ }^{5}$ Chapouthier (1928); Hillbom (2003), p. 74 cat. 88.

${ }^{6}$ Chapouthier (1928).
} 
commonly arranged in a circle or an oval: some of them also have a central (and larger) hole, while a few have a hole that is different from the others in size and position. Some have their holes arranged along a rectangle, and in some cases the holes are arranged in several parallel rows (Fig. 3). These last examples - sometimes with more than 100 holes - are distinctly different from the others, while both the circular and rectangular types share the same characteristics (number of holes, presence/absence of a central hole). The final type consists of a few slabs with holes arranged in a spiral or irregular manner. ${ }^{7}$ Uncertainty about their function is reflected in the variety of names they have been given in the archaeological literature: the rather anonymous "slabs with depressions", pierres à cupules or "Minoan cup-holes" and "cup-marks", but also kernoi and tables à offrandes. The neutral term "slabs with depressions", which corresponds exactly to the expression pierres à cupules, has been adopted for the purposes of this article.

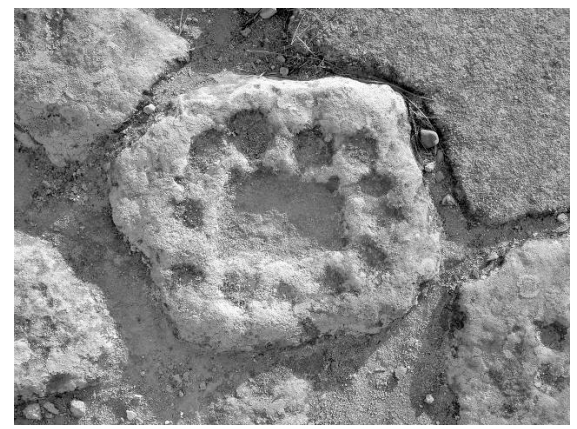

Fig. 2

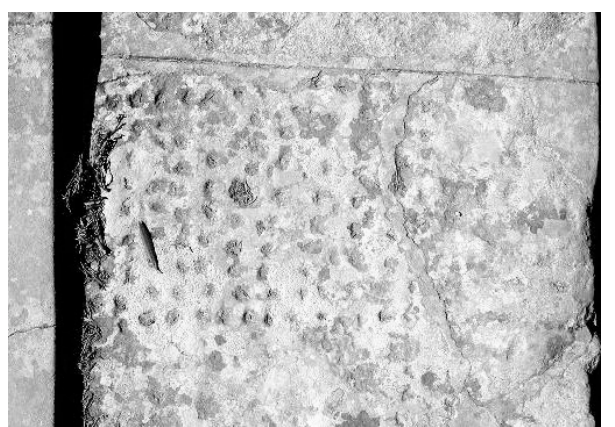

Fig. 3

These objects have been interpreted from a religious viewpoint, by Chapouthier (and, more recently, by Hood), and from a gaming perspective, by Evans (which, more recently, has been the one preferred by $\mathrm{H}$. van Effenterre). ${ }^{8}$ In this latter view, the Mallia stone is a monumental game board, as indicated by analogy with the Egyptian games of senet and mehen and their resemblance to the later tabulae lusoriae. 'This suggestion has been reinforced by the discovery, in some cases, of small objects near the "slabs with depressions" that can be seen as gaming pieces. ${ }^{10}$ Moreover, van Effenterre has found a Greek inscription

\footnotetext{
7 For the classification in these three types of. HoOD (1995); HoOD (2000), p. 608. HiLlBOM (2003), p. 20-24 distinguishes 13 different types.

8 Evans (1921-1935), vol. III, p. 390-396; HoOD (1984); HoOD (1995); HOOD (2000); VAN EfFenterre (1955). Cf. Gesell (1985), p. 7-8, WhitTaker (2002), p. 73-75 and Hillbom (2003), p. 6-10.

${ }^{9}$ WHITTAKER (2002), p. 76-77 with further bibliographical references.

10 Hillbom (2005), p. 311-319. See infra for the small objects found near the slab with depressions discovered ad Dimini.
} 
referring to a naumachia - very probably a game - near a group of holes arranged in a circle on Mount Oxa, on the border between Lato and Olous. ${ }^{11}$

The common view is that it must have been a ritualized game, performed in special circumstances. ${ }^{12}$ This hypothesis does not clash with the possibility that some of the most elaborate "slabs with depressions" (especially the table à offrandes at Mallia) were mainly or only used for religious purposes, as Chapouthier suggests.

In the last few years, the documentation regarding the slabs has been analyzed by $\mathrm{H}$. Whittaker and, most recently, by N. Hillbom, who has put together the most comprehensive catalogue to date, comprising 167 specimens. ${ }^{13}$ In spite of the ambiguity of his book's title, For Gods or for Games, ${ }^{14}$ Hillbom prefers the gaming interpretation for the Minoan "slabs with depressions". Their presence in burial contexts is explained by referring to the Egyptian belief in the game the souls of the dead played with the gods in order to choose their final destination. ${ }^{15}$ Moreover, Hillbom suggests the existence of different games: the " $3 \times 10$ " (probably developed from the Egyptian sehen), the " $10 / 2$ ring", the "12-ring" and so on. ${ }^{16}$

Hillbom's corpus can be complemented with other specimens, bringing the total number of known slabs with depressions to approximately 200. However, in this article, reference will only be made to fixed slabs, and stone vases with rows of holes (which Hillbom considered to be the same as slabs with a rectangular layout of holes) will be excluded. ${ }^{17}$

"Slabs with depressions" have been found in approximately 20 sites in central and eastern Crete, ${ }^{18}$ while none have so far been discovered in western Crete. Prepalatial examples have been found at Myrtos Phournou Koryphi, Vasilikì and Trypitì. Most slabs with depressions, however, date to the protopalatial period. At Knossos, Haghia Triada, Mallia, Gournià and Mochlos, slabs have been discovered in both the settlements and in cemeteries. Local characteristics are probably relevant: at Knossos there are only holes arranged in linear rows,

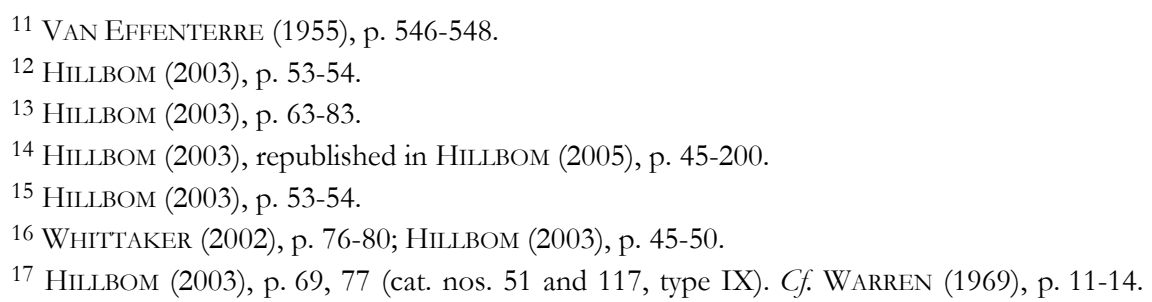
To the slabs with depressions catalogued by Hillbom other specimens can be added from Mallia and Phaistos; see the following footnote for other Cretan sites where slabs with depressions have been discovered.

18 To the sites catalogued by Hillbom (Archanes Anemospilia, Gournia, Jouktas, Kavousi Kastro, Knossos, Kommos, Mallia, Mochlos, Mount Oxa, Myrtos Phournou Koryphi, Phaistos, Pyrgos, Syme Viannou, Trypitì, Vasiliki, Zakros), can be added also Haghia Triada, Kavousi Vronda and Azorià, Pseira. 
with the exception of a couple of LM III specimens belonging to a specific type where the holes are divided into two halves by a line (the so-called "10/2-ring" in Hillbom's classification) that is also found in Crete after the Bronze Age (Kavousi Kastro and Azorià, perhaps Mount Oxa).

The "linear" type, with holes arranged in parallel rows, seems to be more recent than the "circular" type (Fig. 4): in the theatral area at Knossos examples of the former are to be found on the eastern flight of steps, which was added to the architectural complex at a later date. Based on the currently available evidence, the circular type seems to be earlier and more widespread, while the linear type with rows is perhaps later than the protopalatial period. Apart from Knossos, only

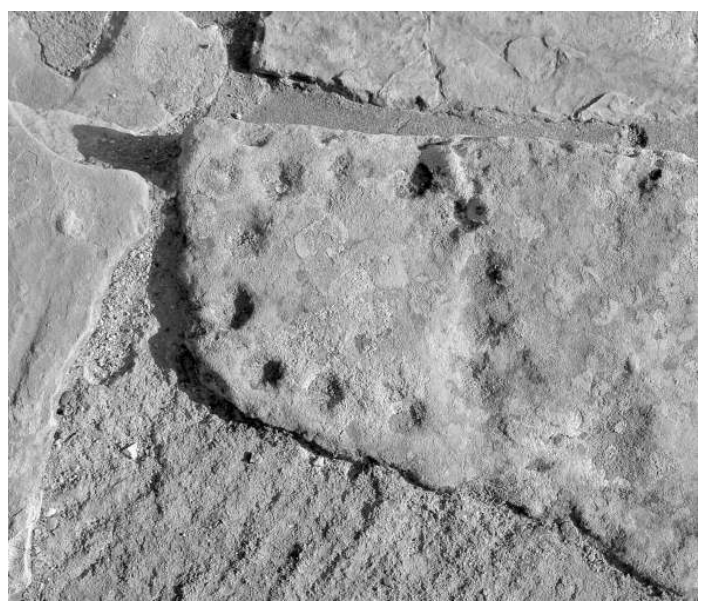

Fig. 4 seven specimens of the linear type are now known. It appears that the circular type variant was added, with the division of the holes in two different halves, during LM III: it has been found at Kavousi Kastro, Azorià and on Mt Oxa, whose "slabs with depressions" are very probably later than the Bronze Age.

The ten "slabs with depressions" thus far found in cemeteries are in fact only seven, once those found in the Isopata Royal Tomb near Knossos in ashlar blocks re-used as construction material are excluded. ${ }^{19}$ Interestingly, the seven "slabs with depressions" date back to the protopalatial period; at Haghia Triada a "slab" is positioned on the floor of a MM I-II room built very near tholos A. ${ }^{20}$ Other rooms nearby contained a large number of vases used in liturgical practices in honour of the dead buried in the tomb, which was used from EM I to MM II. In spite of the small number of slabs in cemeteries, it is important to emphasise their antiquity (at Mallia and Gournia they possibly date to the prepalatial period) and the care taken in their arrangement, in some cases in rooms in which they were an important element.

A possible predecessor to the "slabs with depressions" was found in Final Neolithic levels at Phaistos. Nine holes were purposely cut into the bedrock in the area corresponding to the central court of the Minoan palace; near these were a triton sea-shell, 12 astragaloi and 2 fragmentary vases with red ochre

\footnotetext{
${ }^{19}$ Hillbom (2003), p. 68, cat. 43-45.

${ }^{20}$ LA RosA (2001), p. 225.
} 
decoration. ${ }^{21}$ The Final Neolithic assemblages in the area (which included a large amount of pottery), were recently re-examined by S. Di Tonto and S. Todaro, and attest feasting activities, where enormous quantities of meat were consumed. 22

At Phaistos, "slabs with depressions" are well documented in the protopalatial period, ${ }^{23}$ and in fact this is the site where the largest number has been found (at least 50 specimens $^{24}$ ). Due to the various architectural phases identified in the palace and in the surrounding buildings, it is possible to assign almost all the known specimens to the protopalatial period. ${ }^{25}$ It is important to stress that most of them are to be found in the western court I (Fig. 5), on the steps of the theatral area as well as on the paving (40 specimens).

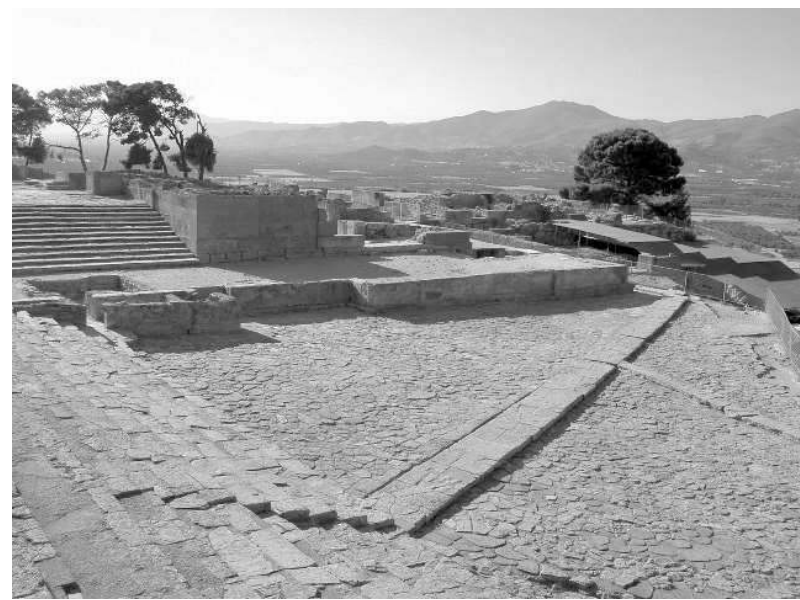

Fig. 5

The connection of "slabs with depressions" to western courts and theatral areas is also evident at other sites: in the settlement at Knossos ten specimens out of 19 are located in the theatral area, while at Mallia 11 out of 23 are in the western court (and one in the Placette ouest of Quartier Mu). At Vasiliki most of the "slabs with depressions" are in the western court, and at

Pseira the only known slab is in the so-called plateia. ${ }^{26}$ A particular concentration of "slabs with depressions" in open areas is also to be found at Gournià, where 15 of the 34 specimens are located in the streets of the settlement.

In the individual settlements there are areas where there is a concentration of "slabs with depressions". These are generally in easily accessible open spaces

${ }^{21}$ LEVI (1957-58), p. 340, fig. 192. Unfortunately there is not a clear picture of the nine holes.

22 TODARO, Di TONTO (2008), p. 186-187. The presence of a human skeleton nearby could testify a possible link between this arrangement and the burial. I thank S. Todaro to have called my attention on this findings.

${ }^{23}$ FERrARI, CUCUZZA (2004).

24 To the 48 "slabs with depressions" (types 1 and 2 of the classification) catalogued by Ferrari, CuCUZZA (2004), three other "slabs with depressions" can be added, located in the protopalatial Piazzale I. The number refers only to the assured specimens.

${ }^{25}$ Ferrari, CuCuZZa (2004), p. 89-90.

${ }^{26}$ Davaras (2001), p. 85, 87. 
such as the western courts (termed "public spaces" by C. Palyvou ${ }^{27}$ ), but also in the lightwells and inner courts of houses: at Gournià there are six specimens in room 4 of protopalatial House Aa.

Apart from the slabs identified in shrines or cult rooms (a total of about ten in the shrines of Juktas, Kato Syme and Gournià, at Anemospilià and in the domestic shrines at Mallia Maison Epsilon Alpha room 6, Mochlos House B2 room 2, Zakros room $\mathrm{H}$ of the protopalatial building under the eastern wing of the palace), the other specimens are usually located near entrances or at thresholds. This is very evident in the protopalatial period, as shown by the "slabs with depressions" at the entrances to the first palace at Phaistos as well as at the Crypte Hypostyle at Mallia. ${ }^{28}$ This feature also occurs in the later stages of the Bronze Age: the table à offrandes is located near the entrance to the palace at Mallia, and a "slab with depressions" dating back to LM IIIC has been found near Building $B$ at Kavousi Vrondà. ${ }^{29}$ Another group of about ten slabs is to be found in rooms linked in some way to storage activities: at Phaistos and Mallia some slabs with depressions are in storerooms from the first palace period. ${ }^{30}$

It is improbable that the concentration of "slabs with depressions" in cult rooms or at the entrances to buildings is accidental, and it is even less likely that this fact was only linked to gaming activity. It must be pointed out that in the largest complex in the whole of Crete - in the protopalatial western court at Phaistos "slabs with depressions" only occur in one well-defined area, delimited by raised walkways

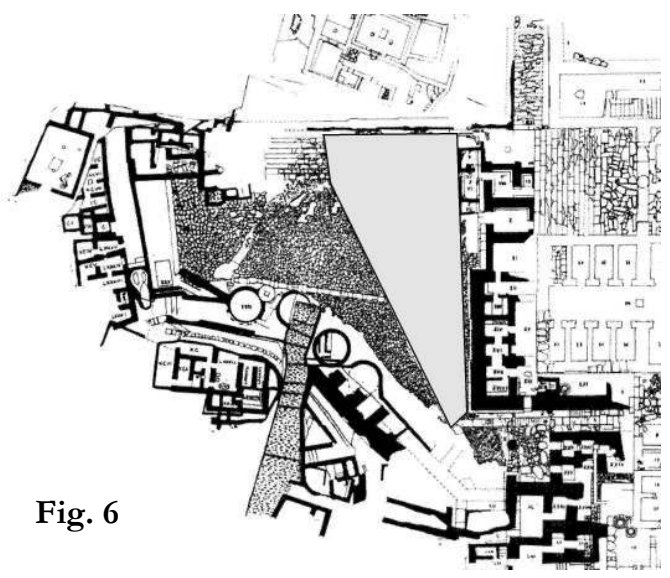
(Fig. 6). The Sacred Grove and Dance Fresco indicate that raised walkways very probably had the function of defining spaces in the western courts during the performance of ritual activities. 31 "Slabs with depressions" were therefore possibly used for a rite during such performances.

\footnotetext{
27 Palyvou (2004), p. 214-215.

28 Hillbom (2003), p. 72 cat. 76 (Mallia), p. 76-77 cat. 111-112 (Phaistos); Ferrari, CucuzZa (2004), p. 72 cat. 79-80 (Phaistos).

29 Preston Day, Coulson, Gesell (1986), p. 365-366.

${ }^{30}$ Hillbom (2003), p. $72-73$ cat. 76, 87 (Mallia); Ferrari, Cucuzza (2004), p. 72-74 cat. 82, 88-89 (Phaistos).

31 Cf. Marinatos (1987), p. 135-143
} 
What then is the link between western courts (with theatral areas), shrines and cult rooms, entrances, storerooms (both of palatial and domestic levels/types) and cemeteries?

Over the last ten years, many studies have pointed to the ceremonial character of the Minoan palaces, emphasising the importance of banquets in the Cretan Bronze Age as a way of legitimizing and negotiating power. ${ }^{32}$ Feasts and banquets took place in the areas of the central courts well before the construction of the first palaces in Crete, ${ }^{33}$ and their importance has been well documented archaeologically by the discovery of large numbers of vases for food and drink. The collective consumption of food very possibly had the function of redistributing goods, i.e. the distribution of equal rations of food and/or beverages. ${ }^{34}$ In Minoan Crete, such redistributive activities are archaeologically attested in Palatial and funerary contexts: the impressive number of conical cups and juglets found in the area of room 25 in the palace at Phaistos is a good example for the protopalatial period. ${ }^{35}$ Curiously enough, a circular lamp was found in an upside-down position in the dump, with a series of conical cups (which were also upside down) placed carefully along its rim: ${ }^{36}$ this feature recalls a protopalatial vessel found in a storeroom in the palatial building at Monastiraki, as well as the well-known vase from Building 6 in the Archanes Phournì cemetery from the same period. ${ }^{37}$

The resemblance of both vases to the "slabs with depressions" is very evident: the link between clay vessels and slabs is even closer in a neopalatial context in House Zeta-Alpha at Mallia: in room 5 several conical cups placed along a circular edge were found on a slab. 38 The vases from Monastiraki and Archanes Phournì are very similar to some Early Cycladic ones: as is well known, in the Cyclades, even in the Early Bronze Age (especially in Phylakopì I culture) composite clay vases - usually referred to as kernoi - were produced and very probably used for offerings. ${ }^{39}$ It is interesting to note that the period when the production of this pottery shape began coincides with that in which the presence of sets for the consumption of alcoholic beverages was recorded, suggesting the practice of funerary banquets. ${ }^{40}$

\footnotetext{
32 Cf. Day, Wilson (2002), p. 148-152 and the papers devoted to the Minoan in Halstead, BARRETT (2004) and HitCHCOCK, LAFFINEUR, CROWLEY (2008).

33 Cf. DRIESSEN (2004).

34 See Rupp, Tsipopoulou (1999) for the conical cups; cf. the use of the "bevelled-rim bowls" in the $4^{\text {th }}$ millennium BC Mesopotamia: LiVERANI (1988), p. 123-127.

${ }^{35}$ LEVI (1976), p. 385-392; Militello (2002), p. 55-62.

${ }^{36}$ LeVI (1976), fig. 604 and 614; Militello (2002), p. 59, fig. 7-8.

37 Kanta, Marazzi (2007), tav. 2a (room 47, Reth. Mus. n. P8725); Girella (2002), p. 169170, 193 (cat. n.11), fig. 1.

38 PrIVITERA (2008), p. 69-70 with references.

39 BARBer (1987), p. 95.

40 Broodbank (2008), p. 60-61.
} 
In protopalatial Crete the redistribution of food and beverages is attested in funerary contexts; hundreds of ceramic vases were found at Haghia Triada in the so-called camerette south of tholos A: in this case, it has been suggested that there was a specific set with a jug, a small plate and four conical cups. ${ }^{41}$

In short, we need to ask whether the use of "slabs with depressions" might be linked to the redistribution that took place in both palatial and funerary contexts, which was a part of clearly religious rites. Redistribution seems to be the common factor between the various contexts where "slabs with depressions" have been found: the find in room 25 at Phaistos, the Monastiraki vase and the arrangement of slab and conical cups in House Zeta-Alpha at Mallia raises questions about the link between "slabs with depressions" and conical cups - certainly the most common form of Minoan vase connected to the idea of equal redistribution, which is attested from the early phases of the prepalatial period. 42

It is thought that there was a link between storage and religion in Minoan Crete; ${ }^{43}$ redistributive activities could therefore have been carried out as part of a religious rite, perhaps including the use of "slabs with depressions" for a ritualized game, as several scholars have inferred. ${ }^{44}$ If correct, it would then be possible to subscribe to the identification of the slabs as kernoi, as proposed by Chapouthier, always bearing in mind, however, the very blurred distinction between religious rituals and games. We should perhaps remember the presence in the central court of the palace and Chrysolakkos tomb at Mallia of several vessels belonging to the same type of vase that could have been used, according to P. Demargne and O. Pelon, to contain a votive offering: ${ }^{45}$ it is tempting to connect these vases with the slabs with depressions discovered near the central court of the palace as well as in the tomb.

In conclusion, it is interesting to note the recent discovery of two "slabs with depressions" which have broadened our knowledge and will undoubtedly be the subject of much future discussion.

The first was a large "slab with depressions" found near an entrance to the socalled Megaron B in the palatial compound excavated at Dimini in Thessaly, which was destroyed at an early stage of LH IIIC. According to V. Adrimi Sismani, the discovery of an altar in the middle of room 1 suggests that Megaron B was a religious building. ${ }^{46}$ The slab with depressions was, however, found on the opposite side of the building: the holes are irregularly positioned, although they

\footnotetext{
${ }^{41}$ LA Rosa (2001), p. 221-227

42 On this pottery shape, WienER (1984), GILLIS (1990); see also WIENER (2006), p. 5-11.

43 On the subject Christakis (2008), p. 139-143.

${ }^{44}$ Hillbom (2003), p. 50-54.

45 PELON (2002), p. 117 pl. XXXIII a-b.

46 Adrimi Sismani (2004-05), p. 39-41, fig. 25; Adrimi Sismani, GodArT (2005), p. 53-55, fig. 3; AdRIMI Sismani (2006), p. 473; ADrimi Sismani (2007).
} 
seem to follow at least two edges of the slab. ${ }^{47}$ Many small objects were found nearby: nine human and six animal figurines, one figurine seated on a throne, a stone seal, a fragment of a kylix with an engraved Linear B inscription (a true ostrakon ${ }^{48}$, pictorial-style sherds, at least one miniature clay vessel, and many bronze pins and leaves. ${ }^{49}$ This find epitomises all the interpretative difficulties of "slabs with depressions": were the figurines and the other small finds gaming pieces or votive offerings? Or perhaps both? It should be pointed out, however, that the position near an entrance to a very large open area is very similar to that of the Minoan slabs. Moreover, the entrance was linked to three rooms used to store vessels (including a large number of kylikes) and other goods designed for the preparation and consumption of food and beverages..$^{50}$

The second new discovery was of three "slabs with depressions" (two of them in situ) on the steps of the Monumental Civic Building at Azorià (Kavousi) in Crete, which was destroyed at the beginning of the 5 th century BC. The two in situ slabs are in a corner and exactly in the middle of the eastern wall of the building; 51 it is difficult to believe that this position is accidental, and it seems to reflect the importance given to the slabs by the people using the monumental building. The link between "slabs with depressions" and steps is reminiscent of the Bronze Age arrangements at Phaistos and Knossos and raises a series of problems. One of these is the function of the slabs: in this case it seems unlikely that they were simply game boards.

Nicola CuCuZZA

Università degli Studi di Genova

Dipartimento di Archeologia e Filologia Classica

Via Balbi, 4

I - 16126 GENOVA

E-mail:Nicola.Cucuzza@lettere.unige.it

\section{List of figures}

Fig. 1. Mallia: the 'Pierre à cupule' in room XVI, 1 (photo by the Author)

Fig. 2. Phaistos: "slab with depressions" in Western Court I (photo by the Author)

Fig. 3. Knossos: "slab with depressions"in the "Theatral Area" (photo by the Author)

Fig. 4. Phaistos: "slab with depressions" in Western Court I (photo by the Author)

Fig. 5. Phaistos: Western Court I from West (photo by the Author)

Fig. 6. Phaistos: plan of the Western Court I: the "slab with depressions" in situ are located in the area marked in grey

47 ADrimi Sismani (2004-2005), p. 44, fig. 29; Adrimi Sismani, GODART (2005), p. 54, fig. 4.

48 IOL Z 2: Adrimi SisMANi, GODART (2005), p. 62; cf. ZURBACH 2006, p. 17-18.

49 Adrimi Sismani (2004-2005), p. 42-44; Adrimi Sismani, GodART (2005), p. 54.

50 Adrimi Sismani (2006), p. 474. Cf. the Palace at Pylos, rooms 18-20 and the use of court 88/63: BENDALL (2004), p. 112-124.

${ }^{51}$ HAGGIS - MOOK (forthcoming); on the building, HAGGIS, MOOK et al. (2007), p. 295-301. 


\section{Bibliography}

Adrimi Sismani, V., "Le palais de Iolkos et sa destruction,” BCH 128-129 (2004-2005), p. 1-54.

Adrimi Sismani, V., "The Palace of Iolkos and its end," in S. Deger-Jalkotzy, I. Lemos (eds.), Ancient Greece. From the Mycenaean Palaces to the Age of Homer, Edinburgh, 2006, p. 465-481.

Adrimi Sismani, V., "Mycenaean Northern Border Revisited: New Evidence from Thessaly," in M.L. Galaty, W.A. Parkinson (eds.), Retbinking Mycenaean Palaces II. Revisited and expanded second edition, Los Angeles, 2007, p. 159-177.

Adrimi Sismani, V., Godart, L., "Les inscriptions en Linéaire B de Dimini/Iolkos et leur contexte archéologique," $A S A A 83$ (2005), p. 47-70.

BARBER, R.L.N., The Cyclades in the Bronze Age, London, 1987.

Bendall, L.M., "Fit for a King? Hierarchy, Exclusion, Aspiration and Desire in the Social Structure of Mycenaean Banqueting," in HALSTEAD, BARRETT (2004), p. 105-135.

Broodbank, C., "The Early Bronze Age in the Cyclades," in C. Shelmerdine (ed.), The Cambridge Companion to the Aegean Bronze Age, Cambridge, 2008, p. 47-76.

Chapouthier, F., "Une table à offrandes au palais de Mallia," BCH 52 (1928), p. 292-323.

CHristakis, K.S., The Politics of Storage. Storage and Sociopolitical Complexity in Neopalatial Crete, Philadelphia, 2008.

Davaras, C., "Comments on the Plateia Building," in Pseira V. The arcbitecture of Pseira, Philadelphia, 2001, p. 79-88.

Day, P.M., WiLson, D.E., "Landscapes of Memory, Craft and Power in Prepalatial and Protopalatial Knossos," in Y. Hamilakis (ed.), Labyrinth Revisited. Rethinking 'Minoan' Archaeology, Oxford, 2002, p. 143-166.

Driessen, J., "The Central Court of the Palace at Knossos," in G. Cadogan, E. Hatzaki, A. VAsilakis (eds.), Knossos: Palace, City, State, London, 2004 (BSA Studies, 12), p. 75-82.

Evans, A., The Palace of Minos at Knossos I-IV, London, 1921-1935.

Ferrari, C., Cucuzza, N., "I cosiddetti kernoi di Festòs," Creta Antica 5 (2004), p. 53-96.

GeselL, G.C., Town, Palace, and House Cult in Minoan Crete, Göteborg, 1985 (SIMA, 67).

GiLlis, C., Minoan Conical Cups. Form, Function and Significance, Göteborg, 1990 (SIMA, 89).

GiReLLA, L., "Vasi rituali con elementi miniaturizzati a Creta, in Egeo e nel Mediterraneo orientale alla fine dell'Età del Bronzo. Indicatori archeologici ed etnici," Creta Antica 3 (2002), p. 167-216.

Haggis, D.C., Mook, M.S., Fitsimons R.D., Scarry C.G., Snyder L.M., "Excavations at Azoria, 2003-2004, Part 1: The Archaic Civic Complex," Hesperia 76 (2007), p. 243-321.

Haggis, D.C., Mook, M.S., "Excavations of an Archaic City at Azoria in Eastern Crete," in Crete in the Geometric and Archaic period (Athens, 27-29 january 2006), forthcoming.

Halstead, P., Barrett J.C. (eds.), Food, Cuisine and Society in Prehistoric Greece (Sheffield, 19-21 january 2001), Sheffield, 2004 (Sheffield Studies in Archaeology, 5).

Hillbom, N., For Games or for Gods? An Investigation of Minoan Cup Holes, Sävedalen, 2003 (SIMA, 132).

Hillbom, N., Minoan Games and Game Boards, Lund, 2005.

Hitchcok, L., Laffineur, R., Crowley, J. (eds.), Dais. The Aegean Feast. Proceedings of the $12^{\text {th }}$ International Aegean Conference (Melbourne, 25-29 March 2008), Liège, 2008 (Aegaeum, 29).

Hood, S., "Games at Knossos?," in Aux origines de l'Hellénisme : la Crète et la Grèce. Hommage à Henri Van Effenterre, Paris, 1984, p. 39-41.

Hoon, S., "Minoan Cup-Marks," Eirene 31 (1995), p. 7-43. 
Hood, S., "Religion in Bronze," in Pepragmena tou H'Diethnes Kretologikou Synedriou (Iraklion, 8-14 septembriou 1996), A1, Iraklio, 2000, p. 607-622.

Kanta, A., MarazZi, M. Monastiraki I. Campagne 2002/2004, Roma, 2007.

La Rosa, V., "Minoan Baetyls: between Funerary Rituals and Epiphanies," in R. LAFFineur, R. HÄGg (eds.), Potnia. Deities and Religion in the Aegean Bronze Age. Proceedings of the $8^{\text {th }}$ International Aegean Conference (Göteborg, 12-15 April 2000), Liège, 2001 (Aegaeum, 22), p. 221-227.

LeVI, D., “Gli scavi a Festòs nel 1956 e 1957," ASAA 35-36 (1957-58), p. 193-361.

LEVI, D., Festòs e la civiltà minoica. I, Roma, 1976.

Liverani, M., Antico Oriente. Storia, società, economia, Roma/Bari, 1988.

Marinatos, N., "Public Festivals in the West Courts of the Palaces," in R. HäGG, N. Marinatos (eds.), The Function of the Minoan Palaces (Athens, 10-16 June 1984), Stockholm, 1987, p. 135-143.

Militello, P., "Amministrazione e contabilità a Festòs II. Il contesto archeologico dei documenti palatini," Creta Antica 3 (2002), p. 51-91.

Palyvou, C., "Outdoor Space in Minoan Architecture: 'Community and Privacy'," in G. Cadogan, E. Hatzaki, A. Vasilakis (eds.), Knossos: Palace, City, State, London, 2004 (BS A Studies, 12), p. 207-217.

Pelon, O., "Contribution du palais de Malia à l'étude et à l'interprétation des 'palais' minoens," in J. Driessen, I. Schoep, R. Laffineur (eds.), Monuments of Minos. Rethinking the Minoan Palaces (Louvain-la-Neuve, 14-15 December 2001), Liège, 2002 (Aegaeum, 23), p. 111-121.

Preston Day, L., Coulson, W.D.E., Gesell, G.C., "Kavousi 1983-1984: the Settlement at Vronda," Hesperia 55 (1986), p. 355-387.

Privitera, S., Case e rituali a Creta nel periodo neopalaziale, Atene, 2008 (Tripodes, 9).

Renfrew, C., The Archeology of Cult. The Shrine at Phylakopi, London, 1985 (ABSA, suppl. 18).

Rupp, D.W., Tsipopoulou, M., "Conical Cup Concentrations at Neopolatial Petras: a Case for Ritualized Reception Ceremony with Token Hospitality," in P.P. BETANCOURT, V. KARAGeOrghis, R. LAFFineur (eds.), Meletemata. Studies in Aegean Archaeology presented to Malcolm H. Wiener as He enters his 65 th year, Liège, 1999 (Aegaeum, 20), p. 721-728.

Todaro, S., Di Tonto, S., "The Neolithic Settlement of Phaistos revisited: Evidence for Ceremonial Activity on the Eve of the Bronze Age," in V. IsAakidou, P. Tomkins (eds.), Escaping the Labyrinth. The Cretan Neolithic in Context, Exeter, 2008 (Sheffield Studies in Archaeo$\log y, 8)$, p. 177-190.

VAN EFFENTERre, H., “Cupules et naumachie,” BCH 79 (1955), p. 541-548.

WARren, P., Minoan Stone V ases, Cambridge, 1969.

Whittaker, H., "Minoan Board Games: the Function and Meaning of Stones with Depressions (so-called Kernoi) from Bronze Age Crete," Aegean Archaeology 6 (2002), p. 73-87.

Wiener, M.H., "Crete and the Cyclades in LM I: the Tale of the Conical Cups," in R. HÄGG, N. Marinatos (eds.), The Minoan Thalassocracy (Athens, 31 May - 5 June 1982), Stockholm, 1984, p. 17-26.

Wiener, M.H., "Pots and Polities," in M.H. Wiener (ed.), Pottery and Society. The Impact of Recent Studies in Minoan Crete. Gold Medallion Colloquium in Honor of Philip P. Betancourt (New Orleans, 5 January 2003), Boston, 2006, p. 1-21.

ZurBACH, J., "Les vases inscrits en Linéaire B. Tentative d'interprétation globale," $M D A I(A) 121$ (2006), p. 13-71. 